\begin{tabular}{lc|l}
\hline Bentham OPEN & The Open Rheumatology Journal & $\begin{array}{l}\text { The Open } \\
\text { Rheumalogy } \\
\text { lournal }\end{array}$ \\
\hline CrossMark & Content list available at: www.benthamopen.com/TORJ/ & DOI: $10.2174 / 1874312901711010062$ \\
\hline
\end{tabular}

RESEARCH ARTICLE

\title{
Biological Effects of Phosphocitrate on Osteoarthritic Articular Chondrocytes
}

\author{
Yubo Sun*, Atiya M Franklin, David R Mauerhan and Edward N Hanley \\ Department of Orthopedic Surgery, Cannon Research, Carolinas Medical Center, PO Box 32861, Charlotte, NC \\ 28232, USA
}

Received: January 30, 2017

Revised: March 06, 2017

Accepted: April 08, 2017

\begin{abstract}
:
Background:

Phosphocitrate (PC) inhibits osteoarthritis (OA) in Hartley guinea pigs. However, the underlying molecular mechanisms remain poorly understood.
\end{abstract}

\section{Objective:}

This study sought to examine the biological effect of PC on OA chondrocytes and test the hypothesis that PC may exert its OA disease modifying effect, in part, by inhibiting the expression of genes implicated in OA disease process and stimulating the production of extracellular matrices.

\section{Method:}

OA chondrocytes were cultured in the absence or presence of PC. Total RNA was extracted and subjected to microarray analyses. The effect of PC on proliferation and chondrocyte-mediated calcification were examined in monolayer culture. The effect of PC on the production of extracellular matrices was examined in micromass culture.

\section{Results:}

PC downregulated the expression of numerous genes classified in proliferation and apoptosis while upregulating the expression of many genes classified in transforming growth factor- $\beta$ (TGF- $\beta$ ) receptor signaling pathway and ossification. PC also downregulated the expressions of many genes classified in inflammatory response and Wnt receptor signaling pathways. Consistent with its effect on the expression of genes classified in proliferation, ossification, and skeletal development, PC inhibited the proliferation of OA chondrocytes and chondrocyte-mediated calcification while stimulating the production of extracellular matrices.

\section{Conclusion:}

PC may exert its OA disease modifying effect, in part, through a crystal-independent mechanism or by inhibiting the expressions of many genes implicated in OA disease process, and at the same time, stimulating the expression of genes implicated in chondroprotection and production of extracellular matrices.

Keywords: Chondrocyte, Calcification, Matrix, Microarray, Osteoarthritis, Phosphocitrate.

\section{INTRODUCTION}

Osteoarthritis (OA) is a degenerative joint disease characterized by gradual loss of articular cartilage, formation of osteophytes, and synovial inflammation. Existing pharmacological interventions for OA remain insufficient. Widely

\footnotetext{
* Address correspondence to this author at the Department of Orthopedic Research Biology, Cannon Research, Carolinas Medical Center, PO Box 32861, Charlotte, NC 28232, USA; Tel: 704/355-5656; Fax: 704/355-5620; E-mail: yubo.sun@carolinashealthcare.org
} 
prescribed non-steroid anti-inflammatory drugs and steroid knee injections only relieve pain and inflammation but have no effects on the progression of cartilage degeneration. There is a need for the development of structural diseasemodifying drugs that not only relieve pain and inflammation but also inhibit or halt the progression of cartilage degeneration. The lack of progress in the development of structural disease-modifying drugs is largely due to our limited understanding of the pathogenesis of OA and insufficient knowledge regarding the molecular targets for therapeutic intervention.

The biochemical events involved in the initiation and progression of OA are poorly understood. Extracellular matrix degrading enzymes and inflammatory cytokines, including matrix metalloproteinases (MMPs), ADAM metallopeptidase with thrombospondin type 1 motif 5 (ADAMTS5), interleukin-1 (IL-1), and tumor necrosis factor alpha (TNF- $\alpha$ ) have been implicated in OA. Small molecules and biologics targeting MMPs, IL-1, and TNF- $\alpha$ have been examined for OA intervention, however, results of clinical trials with MMP inhibitor(s) and biologics against IL-1 and TNF- $\alpha$ were disappointing [1 - 4]. Pathological calcification has also been implicated in OA. Basic calcium phosphate (BCP) crystals and calcium pyrophosphate dihydrate (CPPD) crystals are present in the synovial fluid, menisci, and articular cartilage of patients with end-stage OA [5 - 7]. These crystals stimulated mitogenesis and the production of MMPs and inflammatory cytokines in cell cultures [8 - 11] and induced a severe inflammatory response within the joints of dogs and mice $[12,13]$.

Phosphocitrate (PC) is a powerful calcification inhibitor, inhibiting calcification or formation of calcium crystals by binding to amorphous calcium phosphate aggregates and the surface of calcium crystals. PC inhibited BCP crystalinduced mitogenesis, expression of MMPs, and cell death [14 - 16]. Based on these findings, a hypothesis that PC is potentially a disease-modifying drug for calcification-induced OA therapy was postulated [17]. A subsequent study demonstrated that PC inhibited meniscal calcification and that the reduction in meniscal calcification was accompanied with decreased cartilage degeneration in Hartley guinea pigs [18]. It was believed that PC exerted its disease modifying activity by inhibiting the formation of calcium crystals and the detrimental interactions between these crystals and joint cells (a crystal-dependent mechanism) [17].

We recently demonstrated that PC downregulated the expression of many genes classified in cell proliferation, angiogenesis, and inflammatory response in the absence of calcium crystals in OA fibroblast-like synoviocytes (FLSs) and OA meniscal cells [19 - 21]. These newer findings suggest that PC exerts its OA disease-modifying activity, in part, through a crystal-independent mechanism, directly acting on OA cells instead of acting on calcium crystals. Indeed, PC inhibited cartilage degeneration in Hartley guinea pig model of posttraumatic OA through both a crystal-dependent mechanism and a crystal-independent mechanism [22]. However, the molecular mechanisms remain poorly understood. In this study, we sought to examine the biological effects of $\mathrm{PC}$ on $\mathrm{OA}$ articular chondrocytes and test the hypothesis that PC may exert its OA disease modifying effect, in part, by inhibiting the expression of genes implicated in OA disease process and stimulating the production of extracellular matrices. The information gained from this study may not only shed light on the molecular mechanism underlying the OA disease-modifying activity of PC and provide information valuable for the identification of potential disease candidate genes but also may provide information valuable for a better understanding of the pathogenesis of $\mathrm{OA}$.

\section{MATERIALS AND METHODS}

Dulbecco's modified eagle medium, StemPro osteogenesis differentiation medium, StemPro chondrogenesis differentiation medium, fetal bovine serum, Hank's balanced salt solution, antibiotic and antimycotic solution were products of Invitrogen (Carlsbad, CA). Human foreskin fibroblasts were obtained from American Type Culture Collection (CRL-2429, Manassas, VA). PC was synthesized according to the procedures described [23]. In all experiments, $1 \mathrm{~mm}$ PC was used because it has been used in previous studies and shows no toxic effect on cells [15, 19].

\subsection{OA Articular Chondrocytes}

OA chondrocytes were prepared from articular cartilage specimens collected from 6 end-stage OA patients (age range of 62-68) undergoing joint replacement surgery at Carolinas Medical Center with the approval of the authors' Institutional Review Board. The need for informed consent was waived because those specimens were surgical waste, and no private patient information was collected. Articular cartilage was evaluated as described [24], and only grade 4 cartilages were used. Briefly, articular cartilage was removed from the medial tibia plateau with a surgical blade, minced into small pieces, and cultured in $60 \mathrm{~mm}$ plates at $37^{\circ} \mathrm{C}$ in medium containing $10 \%$ serum and $0.5 \%$ antibiotic/antimycotic solution. Media was changed every 3 days. After chondrocytes reached to $70 \%$ confluence, they 
were passaged. Chondrocytes with 2-3 passages were used in the study.

\subsection{Effect of $P C$ on Gene Expressions}

OA chondrocytes derived from $3 \mathrm{OA}$ patients were harvested from $60 \mathrm{~mm}$ cell culture plates, mixed, and re-plated in $60 \mathrm{~mm}$ plates at $90 \%$ confluence (passage $2 ; 9 \times 10^{6}$ per plate). On the second day, medium containing $1 \%$ serum was added. On the third day, medium in 2 plates was replaced with medium containing $1 \%$ serum and $1 \mathrm{~mm}$ PC and medium in the other 2 plates were replaced with medium containing $1 \%$ serum without PC as a control. Twenty-four hours later, total RNA was extracted using Trizol reagent (Invitrogen, Carlsbad, CA) and purified using the Oligotex kit (Qiagen, Valencia, CA). The quality and integrity of these RNA samples were checked using RNA 6000 Nano Assay Reagent Kit and Agilent 2100 Bioanalyzer (Agilent Technologies, Santa Clara, CA).

RNA samples extracted from two independent experiments were used for microarray analyses. Briefly, doublestranded DNA was synthesized using SuperScript Double-Stranded cDNA Synthesis Kit (Invitrogen, San Diego, CA, USA) using $1 \mu \mathrm{g}$ of each RNA sample. The DNA product was purified using a GeneChip sample cleanup module (Affymetrix, Santa Clara, CA, USA). CRNA was synthesized and biotin labeled using BioArray high yield RNA transcript labeling kit (Enzo Life Sciences, Farmingdale, NY, USA). The cRNA product was purified using GeneChip sample cleanup module and subsequently chemically fragmented. The fragmented and biotinylated cRNA was hybridized to HG-U133_Plus_2.0 gene chip using Affymetrix Fluidics Station 400 (Affymetrix, Santa Clara, CA, USA). The fluorescent signals were quantified during two scans by Agilent Gene Array Scanner G2500A (Agilent Technologies, Palo Alto, CA, USA) and GeneChip operating Software (Affymetrix, Santa Clara, CA, USA). Genesifter (VizX Labs, Seattle, WA, USA) was used for the analysis of differential gene expression and gene ontology. The results of the two microarray experiments were similar, therefore, we focused on the results of the first microarray experiment in this study.

\subsection{Real-time RT-PCR}

The RNA samples used in microarray experiments were used for real-time RT-PCR. Briefly, cDNA was synthesized using TaqMan ${ }^{\circledR}$ Reverse Transcription Reagents (Applied Biosystems, University Park, IL) using $1 \mu \mathrm{g}$ RNA sample. Quantification of relative transcript levels of selected genes and the housekeeping gene glyceraldehyde 3phosphate dehydrogenase (GAPDH) was performed using TaqMan ${ }^{\circledR}$ Gene Expression assay and ABI7000 Real-Time PCR system (Applied Biosystems, University Park, IL). CDNA samples were amplified with an initial Taq DNA polymerase activation step at $95^{\circ} \mathrm{C}$ for 10 minutes, followed by 40 cycles of denaturation at $95^{\circ} \mathrm{C}$ for 15 seconds and annealing at $60^{\circ} \mathrm{C}$ for one minute. Fold change was calculated and the expression level of a specific gene was normalized to the expression level of GAPDH.

\subsection{Effect of $P C$ on the Proliferation of $O A$ Chondrocytes}

OA chondrocytes $\left(2 \times 10^{4}\right)$ were plated in six-well cluster plates and cultured in medium containing $10 \%$ serum in the absence (triplicates) or the presence of $1 \mathrm{mM} \mathrm{PC}$ (triplets). The medium was changed every three days until the chondrocytes in the wells without PC reached to $85 \%$ confluence (it took about 14-16 days). Chondrocytes in all wells were harvested and cell numbers counted. This experiment was repeated three times using OA chondrocytes derived from 3 different OA patients. Trypan blue test was performed to examine the effect of PC on chondrocyte viability. Since foreskin fibroblasts were used in many previous studies to determine the effect of PC on crystal-induced mitogenesis and expression of MMPs [15, 25, 26], foreskin fibroblasts were also used here for comparison.

\subsection{Effect of PC on Chondrocyte-Mediated Calcification}

OA chondrocytes were plated in twenty-four well cluster plates at $90 \%$ confluence $\left(7 \times 10^{5}\right.$ cells). On the second day, the medium was replaced with StemPro osteogenesis differentiation medium with or without $1 \mathrm{~mm}$ PC (triplicates). These chondrocytes were fed with StemPro osteogenesis differentiation medium with or without PC every three days. Fourteen days later, the media were removed and calcium deposition was examined using alizarin red. This experiment was repeated 6 times using OA chondrocytes derived from 6 different OA patients.

\subsection{Effect of PC on the Production of Extracellular Matrices in Micromass Culture}

Micromasses were prepared as described previously [7, 27]. Briefly, OA chondrocytes were harvested from $60 \mathrm{~mm}$ culture plates and suspended in DMEM containing 10\% serum. For preparing a micromass, a droplet of the cell 
suspension containing $2 \times 10^{5}$ chondrocytes was placed in a well of a 24 -well cluster plate. After placing all droplets, the plate was incubated for 4 hours at $37 \mathrm{C}$ in a tissue culture incubator and each of the micromasses formed was then fed with StemPro chondrogenesis differentiation medium. Starting on the next day, these micromasses were fed with StemPro chondrogenesis differentiation medium with PC $(1 \mathrm{mM})$ or without PC every three days.

Fourteen days later each well was rinsed twice with $500 \mu \mathrm{l}$ of Hank's balanced salt solution and two drops of eosin were added. Five minutes later, eosin was aspirated off and the micromasses were transferred to a strip of filter paper which sat on the top of an ethanol-soaked sponge within a plastic cassette. The cassettes sat in a $10 \%$ formalin solution for one hour. These micromasses then underwent routine paraffin embedding. Sections were cut at $5 \mu \mathrm{m}$ thick and stained with picrosirius red for collagens and alcian blue for proteoglycans. This experiment was repeated 3 times using OA chondrocytes derived from 3 different patients.

\subsection{Statistical Analysis}

Results are expressed as the mean \pm standard error. The difference between the PC-treated and untreated group was analyzed using Student's t-test. It was considered significant when the p-value was $<0.01$. Statistical analysis was performed using the statistical analysis tool in the Sigma Plot software, version 12 (Systat software Inc., San Jose, CA).

\section{RESULTS}

\subsection{Effect of PC on Gene Expressions}

Of more than 50,000 transcripts, 558 transcripts displayed differential expression (more than 1.5 fold changes) in PC-treated OA chondrocytes compared to untreated OA chondrocytes. A total of 334 transcripts displayed decreased expression and 224 transcripts displayed increased expression. The genes that fell into specific biological processes implicated in OA or suspected to have a role in OA are listed in (Tables $\mathbf{1}$ and 2).

Table 1. Differentially expressed genes in PC-treated via untreated OA chondrocytes.

\begin{tabular}{|c|c|c|c|c|}
\hline $\begin{array}{c}\text { Biological } \\
\text { process }\end{array}$ & Gene ID & $\begin{array}{c}\text { Gene } \\
\text { Identifier }\end{array}$ & $\begin{array}{c}\text { Fold } \\
\text { change* }\end{array}$ & Description \\
\hline \multicolumn{5}{|l|}{$\begin{array}{c}\text { Cell } \\
\text { proliferation }\end{array}$} \\
\hline & HELLS & NM_018063 & -2.32 & Helicase, lymphoid-specific \\
\hline & NDP & NM_000266 & -2.30 & Norrie disease (pseudoglioma) \\
\hline & EREG & NM_001432 & -2.18 & Epiregulin \\
\hline & KIF15 & NM_020242 & -1.98 & Kinesin family member 15 \\
\hline & SPRY2 & NM_005842 & -1.92 & Sprouty homolog 2 (Drosophila) \\
\hline & ENPP7 & AA701973 & -1.91 & Ectonucleotide pyrophosphatase/phosphodiesterase 7 \\
\hline & E2F7 & $\mathrm{AI} 341146$ & -1.87 & E2F transcription factor 7 \\
\hline & IL7 & NM_000880 & -1.82 & $\begin{array}{l}\text { Interleukin } 7 \\
\end{array}$ \\
\hline & UHRF1 & AK025578 & -1.78 & Ubiquitin-like with PHD and ring finger domains 1 \\
\hline & CDK5R1 & AL567411 & -1.75 & Cyclin-dependent kinase 5 , regulatory subunit 1 (p35) \\
\hline & TACC3 & NM_006342 & -1.75 & Transforming, acidic coiled-coil containing protein 3 \\
\hline & NTN1 & BF591483 & -1.75 & $\begin{array}{l}\text { Netrin } 1 \\
\end{array}$ \\
\hline & EEF1E1 & $\mathrm{N} 32257$ & -1.74 & Eukaryotic translation elongation factor 1 epsilon 1 \\
\hline & TCF19 & BC002493 & -1.74 & Transcription factor 19 \\
\hline & GINS1 & NM_021067 & -1.73 & GINS complex subunit 1 (Psf1 homolog) \\
\hline & NR2F2 & AL554245 & -1.72 & Nuclear receptor subfamily 2 , group F, member 2 \\
\hline & CCND1 & BC000076 & -1.68 & Cyclin D1 \\
\hline & SOX4 & AI989477 & -1.67 & SRY (sex determining region Y)-box 4 \\
\hline & MEF2C & $\mathrm{N} 22468$ & -1.66 & Myocyte enhancer factor 2C \\
\hline & CDKN2D & U20498 & -1.63 & Cyclin-dependent kinase inhibitor 2D (p19, inhibits CDK4) \\
\hline & HBEGF & NM_001945 & -1.62 & Heparin-binding EGF-like growth factor \\
\hline & FOSL1 & BG251266 & -1.58 & FOS-like antigen 1 \\
\hline & MKI67 & AU152107 & -1.58 & Antigen identified by monoclonal antibody Ki-67 \\
\hline & TRIM24 & NM_015905 & -1.57 & Tripartite motif-containing 24 \\
\hline & SPHK1 & NM_021972 & -1.56 & Sphingosine kinase 1 \\
\hline
\end{tabular}


(Table $\square$ ) contd......

\begin{tabular}{|c|c|c|c|c|}
\hline $\begin{array}{c}\text { Biological } \\
\text { process }\end{array}$ & Gene ID & $\begin{array}{c}\text { Gene } \\
\text { Identifier }\end{array}$ & $\begin{array}{c}\text { Fold } \\
\text { change* }\end{array}$ & Description \\
\hline & BLM & NM_000057 & -1.55 & Bloom syndrome, RecQ helicase-like \\
\hline & BMP2 & NM_001200 & -1.55 & Bone morphogenetic protein 2 \\
\hline & ACER3 & R12678 & -1.55 & Alkaline ceramidase 3 \\
\hline & CDCA7 & AY029179 & -1.52 & Cell division cycle associated 7 \\
\hline & CDC20 & NM_001255 & -1.50 & Cell division cycle 20 homolog (S. cerevisiae) \\
\hline & B4GALT1 & M22921 & 2.20 & UDP-Gal:betaGlcNAc beta 1,4- galactosyltransferase, polypeptide 1 \\
\hline & FGFR2 & M80634 & 1.99 & Fibroblast growth factor receptor 2 \\
\hline & EGR1 & AI459194 & 1.98 & Early growth response 1 \\
\hline & TXNIP & AA812232 & 1.82 & Thioredoxin interacting protein \\
\hline & TGFBR1 & AV700621 & 1.74 & Transforming growth factor, beta receptor 1 \\
\hline & DDR2 & AA545764 & 1.58 & Discoidin domain receptor tyrosine kinase 2 \\
\hline & CSF1 & $\mathrm{U} 22386$ & 1.55 & Colony stimulating factor 1 (macrophage) \\
\hline & IGFBP5 & R73554 & 1.53 & Insulin-like growth factor binding protein 5 \\
\hline & ARIH2 & AW074830 & 1.51 & Ariadne homolog 2 (Drosophila) \\
\hline \multicolumn{5}{|l|}{ Apoptosis } \\
\hline & HELLS & NM_018063 & -2.32 & Helicase, lymphoid-specific \\
\hline & DUSP6 & $\mathrm{BC} 003143$ & -2.30 & Dual specificity phosphatase 6 \\
\hline & SPRY2 & NM_005842 & -1.92 & Sprouty homolog 2 (Drosophila) \\
\hline & PCGF2 & NM_007144 & -1.89 & Polycomb group ring finger 2 \\
\hline & IL7 & NM_000880 & -1.82 & Interleukin 7 \\
\hline & BIRC5 & AA648913 & -1.76 & Baculoviral IAP repeat-containing 5 \\
\hline & CDK5R1 & AL567411 & -1.75 & Cyclin-dependent kinase 5, regulatory subunit $1(\mathrm{p} 35)$ \\
\hline & RASSF5 & $\mathrm{BC} 004270$ & -1.75 & Ras association (RalGDS/AF-6) domain family member 5 \\
\hline & NTN1 & BF591483 & -1.75 & Netrin 1 \\
\hline & EEF1E1 & N32257 & -1.74 & Eukaryotic translation elongation factor 1 epsilon 1 \\
\hline & PAK1 & AU147145 & -1.73 & $\mathrm{P} 21$ protein $(\mathrm{Cdc} 42 / \mathrm{Rac})$-activated kinase 1 \\
\hline & BCAP29 & AL583687 & -1.72 & B-cell receptor-associated protein 29 \\
\hline & LMNB1 & NM_005573 & 1.70 & Lamin B1 \\
\hline & EPHA2 & NM_004431 & -1.69 & EPH receptor A2 \\
\hline & PHLDA1 & AK026181 & -1.68 & Pleckstrin homology-like domain, family A, member 1 \\
\hline & ALDH1A3 & NM_000693 & -1.67 & Aldehyde dehydrogenase 1 family, member A3 \\
\hline & ALKBH1 & AI922200 & -1.67 & AlkB, alkylation repair homolog 1 (E. coli) \\
\hline & $\mathrm{SOX} 4$ & AI989477 & -1.67 & SRY (sex determining region Y)-box 4 \\
\hline & $\mathrm{MEF} 2 \mathrm{C}$ & N22468 & -1.66 & Myocyte enhancer factor $2 \mathrm{C}$ \\
\hline & RNF130 & AL831873 & -1.64 & Ring finger protein 130 \\
\hline & CDKN2D & U20498 & -1.63 & Cyclin-dependent kinase inhibitor 2D (p19, inhibits CDK4) \\
\hline & FOSL1 & BG251266 & -1.58 & FOS-like antigen 1 \\
\hline & TRIM24 & NM_015905 & -1.57 & Tripartite motif-containing 24 \\
\hline & SPHK1 & NM_021972 & -1.56 & Sphingosine kinase 1 \\
\hline & BMP2 & NM_001200 & -1.55 & Bone morphogenetic protein 2 \\
\hline & $\mathrm{CDC} 2$ & AL524035 & -1.54 & Cell division cycle $2, \mathrm{G} 1$ to $\mathrm{S}$ and $\mathrm{G} 2$ to $\mathrm{M}$ \\
\hline & CRADD & U79115 & -1.53 & CASP2 and RIPK1 domain containing adaptor with death domain \\
\hline & EXPL1 & D79987 & -1.53 & extra spindle pole bodies homolog 1 (S. cerevisiae) \\
\hline & PHLDA1 & NM_007350 & -1.52 & Pleckstrin homology-like domain, family A, member 1 \\
\hline & MAP1S & NM_018174 & -1.52 & Microtubule-associated protein 1S \\
\hline & MCL1 & BF594446 & 2.33 & Myeloid cell leukemia sequence 1 (BCL2-related) \\
\hline & B4GALT1 & M22921 & 2.20 & UDP-Gal:betaGlcNAc beta 1,4- galactosyltransferase, polypeptide 1 \\
\hline & MX1 & NM_002462 & 2.02 & Myxovirus resistance 1, interferon-inducible protein p78 (mouse) \\
\hline & FGFR2 & M80634 & 1.99 & Fibroblast growth factor receptor 2 \\
\hline & TXNIP & AA812232 & 1.82 & Thioredoxin interacting protein \\
\hline & TGFBR1 & AV700621 & 1.74 & Transforming growth factor, beta receptor 1 \\
\hline & ARRB2 & NM_004313 & 1.61 & Arrestin, beta 2 \\
\hline & SMAD3 & BF971416 & 1.55 & SMAD family member 3 \\
\hline
\end{tabular}




\begin{tabular}{|c|c|c|c|c|}
\hline $\begin{array}{c}\text { Biological } \\
\text { process }\end{array}$ & Gene ID & $\begin{array}{c}\text { Gene } \\
\text { Identifier }\end{array}$ & $\begin{array}{c}\text { Fold } \\
\text { change* }\end{array}$ & Description \\
\hline \multicolumn{5}{|l|}{$\begin{array}{l}\text { TGF- } \beta \\
\text { receptor } \\
\text { signaling } \\
\text { pathway }\end{array}$} \\
\hline & TGFBR1 & AV700621 & 1.74 & Transforming growth factor, beta receptor 1 \\
\hline & ARRB2 & NM_004313 & 1.61 & Arrestin, beta 2 \\
\hline & C5orf13 & U36189 & 1.59 & Chromosome 5 open reading frame 13 \\
\hline & SMURF1 & $\mathrm{AC} 004893$ & 1.57 & SMAD specific E3 ubiquitin protein ligase 1 \\
\hline & SMAD3 & BF971416 & 1.55 & SMAD family member 3 \\
\hline \multicolumn{5}{|l|}{ Ossification } \\
\hline & FGFR2 & M80634 & 1.99 & Fibroblast growth factor receptor 2 \\
\hline & RSAD2 & AW189843 & 1.63 & Radical S-adenosyl methionine domain containing 2 \\
\hline & PDLIM7 & AW206786 & 1.57 & PDZ and LIM domain 7 (enigma) \\
\hline & SMURF1 & $\mathrm{AC} 004893$ & 1.57 & SMAD specific E3 ubiquitin protein ligase 1 \\
\hline & IGFBP5 & R73554 & 1.53 & Insulin-like growth factor binding protein 5 \\
\hline & ENPP1 & BF057080 & -1.66 & Ectonucleotide pyrophosphatase/phosphodiesterase 1 \\
\hline & BMP2 & NM_001200 & -1.55 & Bone morphogenetic protein 2 \\
\hline
\end{tabular}

*Negative number indicates decreased expression and positive number indicates increased expression (fold change) in PC-treated OA chondrocytes compared with untreated OA chondrocytes.

Table 2. Differentially expressed genes in PC-treated via untreated OA chondrocytes.

\begin{tabular}{|c|c|c|c|c|}
\hline & Gene ID & $\begin{array}{c}\text { Gene } \\
\text { Identifier }\end{array}$ & $\begin{array}{c}\text { Fold } \\
\text { change* }\end{array}$ & Description \\
\hline \multicolumn{5}{|l|}{$\begin{array}{l}\text { Inflammatory } \\
\text { response }\end{array}$} \\
\hline & FABP4 & NM_001442 & -2.11 & Fatty acid binding protein 4 , adipocyte \\
\hline & IRAK2 & AI246590 & -1.71 & Interleukin-1 receptor-associated kinase 2 \\
\hline & IL1RAP & AF167343 & -1.57 & Interleukin 1 receptor accessory protein \\
\hline & BMP2 & NM_001200 & -1.55 & Bone morphogenetic protein 2 \\
\hline & B4GALT1 & M22921 & 2.20 & $\begin{array}{c}\text { UDP-Gal:betaGlcNAc beta 1,4- galactosyltransferase, } \\
\text { polypeptide } 1\end{array}$ \\
\hline & FN1 & AJ276395 & 1.92 & $\begin{array}{l}\text { Fibronectin } 1 \\
\end{array}$ \\
\hline \multicolumn{5}{|l|}{$\begin{array}{c}\text { Skeletal system } \\
\text { development }\end{array}$} \\
\hline & DLX2 & NM_004405 & -2.37 & Distal-less homeobox 2 \\
\hline & PCGF2 & NM_007144 & -1.89 & Polycomb group ring finger 2 \\
\hline & EPHA2 & NM_004431 & -1.69 & EPH receptor A2 \\
\hline & POSTN & AW137148 & -1.56 & Periostin, osteoblast specific factor \\
\hline & BMP2 & NM_001200 & -1.55 & Bone morphogenetic protein 2 \\
\hline & FGFR2 & M80634 & 1.99 & Fibroblast growth factor receptor 2 \\
\hline & TGFBR1 & AV700621 & 1.74 & Transforming growth factor, beta receptor 1 \\
\hline & RDH10 & NM_172037 & 1.62 & Retinol dehydrogenase 10 (all-trans) \\
\hline \multicolumn{5}{|l|}{$\begin{array}{l}\text { Wnt receptor } \\
\text { signaling } \\
\text { pathways }\end{array}$} \\
\hline & APCDD1 & N48299 & -2.68 & Adenomatosis polyposis coli down-regulated 1 \\
\hline & NDP & NM_000266 & -2.30 & Norrie disease (pseudoglioma) \\
\hline & CCND1 & BC000076 & -1.68 & Cyclin D1 \\
\hline & SOX4 & AI989477 & -1.67 & SRY (sex determining region Y)-box 4 \\
\hline & FZD8 & $\mathrm{AB} 043703$ & -1.58 & Frizzled homolog 8 (Drosophila) \\
\hline & BMP2 & NM_001200 & -1.55 & Bone morphogenetic protein 2 \\
\hline & FGFR2 & M80634 & 1.99 & Fibroblast growth factor receptor 2 \\
\hline & SMAD3 & BF971416 & 1.55 & SMAD family member 3 \\
\hline
\end{tabular}

*Negative number indicates decreased expression and positive number indicates increased expression (fold change) in the PC-treated OA chondrocyte compared with the untreated OA chondrocytes. 
As shown in Table 1, the expression of numerous genes classified in proliferation and apoptosis was down-regulated by PC. Of the 39 differentially-expressed genes classified in cell proliferation, the expression of 30 genes, including lymphoid-specific helicase (HELLS, -2.32 fold) and interleukin 7 (IL-7, -1.82 fold), was down-regulated by PC. Of the 38 differentially-expressed genes classified in apoptosis, the expression of 30 genes, including sprouty homolog 2 (SPRY2, -1.92 fold) and baculoviral IAP repeat-containing 5 (BIRC5, -1.76 fold), was down-regulated by PC. In contrast, the expression of many genes classified in the transforming growth factor $\beta$ (TGF- $\beta$ ) receptor signaling pathway and ossification were upregulated by PC. Of the 5 differentially-expressed genes classified in the TGF- $\beta$ receptor signaling pathway, the expression of all 5 genes, including TGF-beta receptor 1 (TGFBR1, 1.74 fold), SMAD specific E3 ubiquitin protein ligase 1 (SMURF1, 1.57 fold), and SMAD family member 3 (SMAD3, 1.55 fold), was upregulated by PC. Of the 7 differentially-expressed genes classified in ossification, the expression of 5 genes, including fibroblast growth factor receptor 2 (FGFR2, 1.99 fold), PDZ and LIM domain 7 (PDLIM7, 1.57 fold), and insulin-like growth factor binding protein 5 (IFGBP5, 1.53 fold), was up-regulated by PC. However, ectonucleotide pyrophosphatase 1 (ENPP1, -1.66 fold) and bone morphogenetic protein 2 (BMP2, -1.55 fold), two genes implicated in promoting ossification, was down-regulated by PC.

The expression of many genes classified in the inflammatory response, skeletal system development, and Wnt receptor signaling pathway was also downregulated by PC (Table 2). Of the 6 differentially-expressed genes classified in the inflammatory response, the expression of 4 genes, including fatty acid-binding protein 4 (FABP4; -2.11 fold), interleukin-1 receptor-associated kinase 2 (IRAK2, -1.71), and interleukin 1 receptor accessory protein (IL1RAP, -1.57), were down-regulated by PC of the 8 differentially-expressed genes classified in skeletal system development, the expression of 5 genes, including distal-less homeobox 2 (DLX2, -2.37 fold) and periostin (POSTN, -1.56 fold) was down-regulated by $\mathrm{PC}$, of the 8 differentially-expressed genes classified in the Wnt receptor signaling pathway, the expression of 6 genes, including adenomatosis polyposis coli down-regulated 1 (APCDD1, -2.68 fold), norrie disease (NDP, -2.30 fold), and frizzled homolog 8 (FZD8, -1.58 fold), was down-regulated by PC.

\subsection{Real-Time RT-PCR}

Real-time RT-PCR was performed to confirm the differential expression of selected genes. As shown in Table $\mathbf{3}$, the differential expression of the genes examined was confirmed by real-time RT-PCR $(\mathrm{P}<0.01)$.

Table 3. Differential expression confirmed by real-time RT-PCR.

\begin{tabular}{|c|c|c|c|}
\hline Gene ID & Gene Identifier & $\begin{array}{c}\text { Differential Expression } \\
\text { Microarray }\end{array}$ & $\begin{array}{c}\text { Differential Expression } \\
\text { RT-PCR }\end{array}$ \\
\hline HELLS & NM_018063 & -2.32 & -2.97 \\
\hline NDP & NM_000266 & -2.30 & -2.01 \\
\hline CCND1 & BC000076 & -1.68 & -2.03 \\
\hline IL7 & NM_000880 & -1.82 & -1.75 \\
\hline ENPP1 & BF057080 & -1.66 & -1.92 \\
\hline FABP4 & NM_001442 & -2.11 & -1.81 \\
\hline THBD & NM_000361 & -2.57 & -2.04 \\
\hline PLAT & NM_000930 & -2.34 & -2.50 \\
\hline FGFR2 & M80634 & 1.99 & 1.59 \\
\hline SMAD3 & BF971416 & 1.53 & 1.45 \\
\hline IGFBP5 & R73554 & \\
\hline
\end{tabular}

\subsection{PC Inhibits Proliferation of OA Chondrocytes}

The down-regulatory effect of PC on the expression of numerous genes classified in cell proliferation suggests that PC inhibits the proliferation of OA chondrocytes. Indeed, there were roughly $45 \%$ fewer OA chondrocytes in the wells containing PC compared to the wells containing no PC Fig. (1). The morphology of OA chondrocytes in the wells with and without PC was similar and trypan blue test showed little dead cells in both the untreated and PC-treated chondrocytes (not shown). 


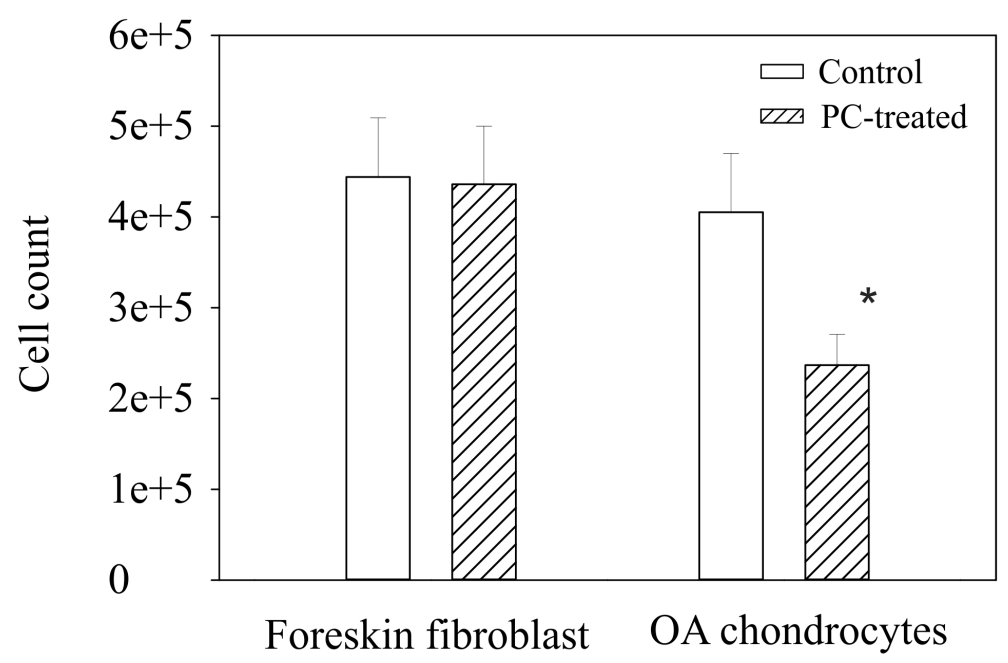

Fig. (1). Effect of PC on chondrocyte proliferation. Left bar group-numbers of foreskin fibroblasts cultured in the absence and presence of PC. No effect was noted. Right bar group - numbers of OA chondrocytes cultured in the absence and presence of PC. PC inhibited the proliferation of OA chondrocytes. $*=p<0.01$ versus untreated control.

\subsection{PC Inhibits OA Chondrocyte-Mediated Calcification}

To investigate the OA chondrocyte-mediated calcification, we cultured OA chondrocytes in osteogenetic differentiation medium. As shown in Fig. (2), calcium deposits were detected in the monolayer of OA chondrocytes cultured in osteogenetic differentiation medium in the absence of PC, but not in the presence of $1 \mathrm{~mm}$ PC. These findings demonstrated that $\mathrm{OA}$ chondrocytes were capable of producing calcium crystals and that PC inhibited this calcification process.

Control

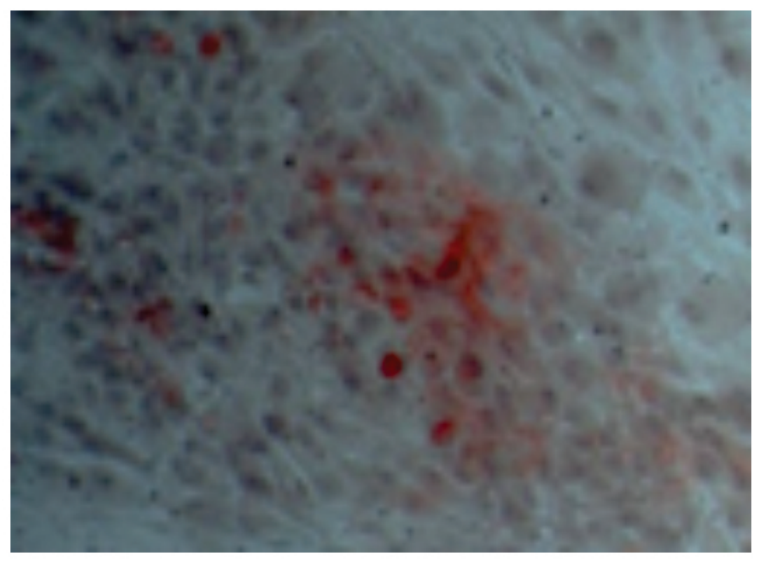

PC-treated

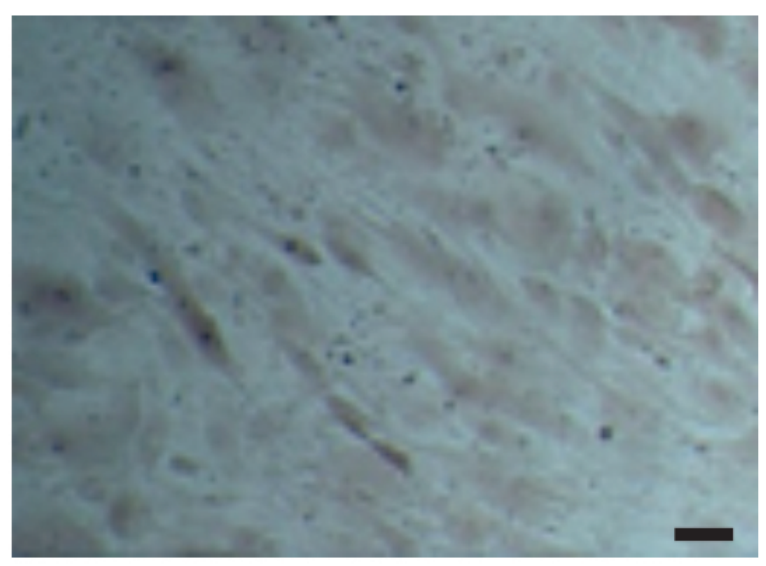

Fig. (2). Representative images of alizarin red stained OA chondrocytes. Calcium deposits were detected in monolayer of OA chondrocytes cultured in osteogenetic differentiation medium, but not in the monolayer of OA chondrocytes cultured in osteogenetic differentiation medium containing $1 \mathrm{~mm}$ PC. $(\mathrm{bar}=10 \mu \mathrm{m})$.

\subsection{PC Stimulates the Production of Cartilaginous Extracellular Matrices}

Representative images of untreated and PC-treated micromasses of OA chondrocytes are provided in Fig. (3). As shown, the intensity of picrosirius red staining in the outer layer of the PC-treated micromass of OA chondrocytes was higher than the intensity of picrosirius red staining in the outer layer of the untreated micromass, indicating that PC stimulated the production of collagens by OA chondrocytes. The intensity of alcian blue staining in the outer layer of the PC-treated micromass of OA chondrocytes was also higher than the intensity of alcian blue staining in the untreated micromass, indicating that PC also stimulated the production of proteoglycans by OA chondrocytes. 

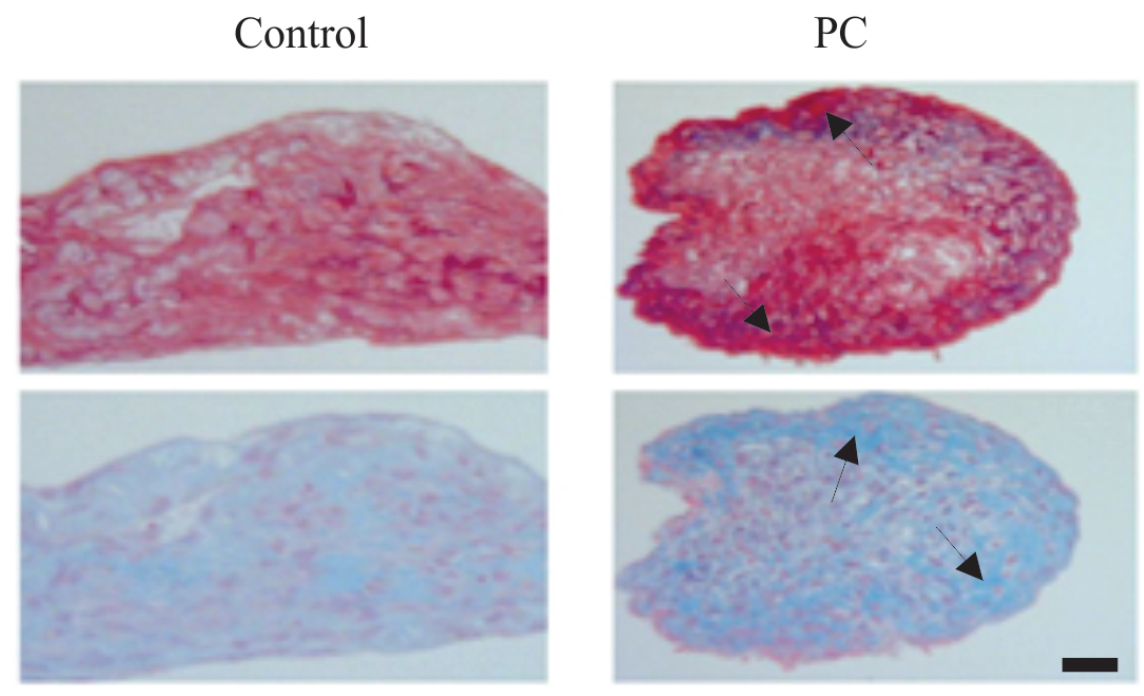

Fig. (3). Representative images of picrosirius red and alcian blue stained sections of micromasses of OA chondrocytes. Arrows outer layers of the micromasses of OA chondrocytes. $(\mathrm{bar}=100 \mu \mathrm{m})$. PC stimulated the production of collagens and proteoglycans.

\section{DISCUSSION}

Increased number and size of chondrocyte clusters are hallmark histological features of OA articular cartilage [28, 29]. The number of proliferating chondrocytes increased during OA progression [29,30] and the clusters contained apoptotic chondrocytes [29 - 32]. One of the potential mechanisms of apoptosis is abnormal differentiation of OA chondrocytes and subsequent calcification [33,34]. OA cartilage showed co-localization of chondrocyte clusters and calcium deposits adjacent to apoptotic chondrocytes [35]. These previous findings indicate that chondrocyte activation, differentiation, calcification, and apoptosis are mutually linked OA disease processes. In this study, we demonstrate that PC downregulated the expression of numerous genes classified in proliferation and apoptosis in OA chondrocyte culture in the absence of calcium crystals. Consistent with its gene expression-regulatory effects, PC inhibited the proliferation of OA chondrocytes and chondrocyte-mediated calcification. These findings together indicate that PC can act directly on OA chondrocytes (a crystal-independent action of PC) in addition to calcium crystals (a crystal-dependent action of PC). PC may exert its OA disease-modifying activity, in part, by targeting genes involved in chondrocyte activation, apoptosis, and calcification, and in so doing, inhibiting chondrocyte apoptosis and chondrocyte-mediated calcification $[36,37]$.

Several previous findings appeared to be consistent with this new molecular mechanism. For examples, IL-7 (classified in proliferation) level was higher in OA chondrocytes and stimulated the production of MMP-13 [38]; HELLS (classified in proliferation and apoptosis) promoted cell activation [39]; BIRC5 (classified in apoptosis) was observed in chondrocytes within degraded lesions and was positively associated with apoptotic chondrocytes [40]. In this study, we demonstrated that PC down-regulated the expression of these 3 genes: IL-7, HELLS, and BIRC5. In addition, a recent study demonstrated that signaling via TGFBR1 (Smad2/3 route) resulted in a protective response whereas signaling via activin A receptor type II-like 1 (ACVRL1) (Smad1/5/8 route) resulted in a deleterious response in articular chondrocytes [41]. The ratio of ACVRL1/TGFBR1 was significantly increased in the cartilage of aging mice, favoring TGF- $\beta$ signaling via the Smad1/5/8 route, inducing changes in chondrocyte differentiation and MMP-13 expression [41]. These previous findings indicate that reduced signaling via TGFBR1 (Smad2/3 route) may play a role OA. Studies also demonstrated that inhibition of SMURF1-mediated degradation of Smad1/5 increased BMP-2 signal responsiveness and enhanced osteoblastic activity [42] and that intracellular delivery of SMURF1 inhibited BMP-2induced alkaline phosphatase activity and downregulated BMP receptors [43, 44]. Remarkably, PC upregulated the expression of TGFRB1, Smad3, and SMURF1 in the OA chondrocytes. This up-regulatory effect indicates that PC may exert its OA disease modifying effect or chondroprotective effects, in part, by enhancing the signaling via the TGFBR1 and $\operatorname{Smad} 2 / 3$ route while suppressing the signaling via IL-7, Smad1/5, and BMP-2 route.

Previous studies showed that inhibition of IGFBP5 proteolysis reduced articular cartilage degeneration [45 - 47], PDLIM7 inhibited MMP production [48], and that the expression of FGFR2 was decreased in degenerated cartilage [49]. These previous findings indicate that IGFBP5, PDLIM7, and FGFR2 are potentially chondroprotective proteins. In 
contrast, BMP-2 is potentially a disease candidate gene. The level of BMP-2 was elevated in serum, synovial fluid, and chondrocytes derived from OA patients and BMP2 induced chondrocyte hypertrophy and osteophyte formation [50 52]. Here, we demonstrated that PC up-regulated the expression of IGFBP5, PDLIM7, and FGFR2 while downregulated the expression of BMP2. This differential effect of PC on the expression of these genes indicates that PC may exert its OA disease modifying effect, in part, by stimulating the production of chondroprotective proteins and inhibiting pathological ossification stimulated by BMP2.

Of the genes classified in the inflammatory response, skeletal system development, and wnt receptor signaling pathways, PC downregulated the expression of FABP4, IRAK2, DLX2, POSTN, APCDD1, NDP, SOX4, and FZD8. These genes have either been previously implicated in arthritis or terminal differentiation of chondrocytes. For example, serum FABP4 was increased in patients with rheumatoid arthritis and metabolic syndrome [53, 54]; DLX2 promoted osteogenic differentiation of stem cells and enhanced mineralization [55]; POSTN induced the expression of IL-6, IL-8, and MMPs [56]; APCDD1 was associated with increased expression of RunX2 and elevated alkaline phosphatase activity [57]; NDP activated Wnt/ $\beta$-catenin pathway associated with OA [58, 59]; SOX-4 signaling resulted in repression of SOX-9, a master transcription factor critical for chondrogenesis [60]; Silence of FZD8 resulted in decreased expression of MMP-3 [61]. The downregulation of the expression of these genes by PC was consistent with its OA disease-modifying activity.

\section{CONCLUSION}

In conclusion, $\mathrm{PC}$ can act directly on $\mathrm{OA}$ chondrocytes in the absence of calcium crystals. PC may exert its $\mathrm{OA}$ disease modifying effect, in part, through a crystal-independent mechanism or by inhibiting the expressions of genes implicated in chondrocyte activation, proliferation, apoptosis, calcification, and inflammatory response while stimulating the expressions of many genes implicated in chondroprotection and matrix production in chondrocytes.

\section{ETHICS APPROVAL AND CONSENT TO PARTICIPATE}

Not applicable.

\section{HUMAN AND ANIMAL RIGHTS}

No Animals/Humans were used for studies that are base of this research.

\section{CONSENT FOR PUBLICATION}

Not applicable.

\section{CONFLICT OF INTEREST}

The authors confirm that this article content has no conflict of interest.

\section{ACKNOWLEDGEMENTS}

This study is supported in part by a Charlotte-Mecklenburg Education and Research Foundation Grant (to YS).

\section{REFERENCES}

[1] Hellio Le Graverand-Gastineau MP. OA clinical trials: current targets and trials for OA. Choosing molecular targets: what have we learned and where we are headed? Osteoarthritis Cartilage 2009; 17(11): 1393-401. [http://dx.doi.org/10.1016/j.joca.2009.04.009] [PMID: 19426849]

[2] Burrage PS, Brinckerhoff CE. Molecular targets in osteoarthritis: metalloproteinases and their inhibitors. Curr Drug Targets 2007; 8(2): 293-303.

[http://dx.doi.org/10.2174/138945007779940098] [PMID: 17305507]

[3] Calich AL, Domiciano DS, Fuller R. Osteoarthritis: can anti-cytokine therapy play a role in treatment? Clin Rheumatol 2010; 29(5): 451-5. [http://dx.doi.org/10.1007/s10067-009-1352-3] [PMID: 20108016]

[4] Malemud CJ. Anticytokine therapy for osteoarthritis: evidence to date. Drugs Aging 2010; 27(2): 95-115. [http://dx.doi.org/10.2165/11319950-000000000-00000] [PMID: 20104937]

[5] Nalbant S, Martinez JA, Kitumnuaypong T, Clayburne G, Sieck M, Schumacher HR Jr. Synovial fluid features and their relations to osteoarthritis severity: new findings from sequential studies. Osteoarthritis Cartilage 2003; 11(1): 50-4. [http://dx.doi.org/10.1053/joca.2002.0861] [PMID: 12505487] 
[6] Fuerst M, Bertrand J, Lammers L, et al. Calcification of articular cartilage in human osteoarthritis. Arthritis Rheum 2009; 60(9): 2694-703. [http://dx.doi.org/10.1002/art.24774] [PMID: 19714647]

[7] Sun Y, Mauerhan DR, Honeycutt PR, et al. Calcium deposition in osteoarthritic meniscus and meniscal cell culture. Arthritis Res Ther 2010; 12(2): R56.

[http://dx.doi.org/10.1186/ar2968] [PMID: 20353559]

[8] McCarthy GM, Mitchell PG, Cheung HS. The mitogenic response to stimulation with basic calcium phosphate crystals is accompanied by induction and secretion of collagenase in human fibroblasts. Arthritis Rheum 1991; 34(8): 1021-30. [http://dx.doi.org/10.1002/art.1780340812] [PMID: 1650221]

[9] Sun Y, Wenger L, Brinckerhoff CE, Misra RR, Cheung HS. Basic calcium phosphate crystals induce matrix metalloproteinase-1 through the Ras/mitogen-activated protein kinase/c-Fos/AP-1/metalloproteinase 1 pathway. Involvement of transcription factor binding sites AP-1 and PEA-3. J Biol Chem 2002; 277(2): 1544-52 [http://dx.doi.org/10.1074/jbc.M100567200] [PMID: 11682465]

[10] Ea HK, Uzan B, Rey C, Lioté F. Octacalcium phosphate crystals directly stimulate expression of inducible nitric oxide synthase through p38 and JNK mitogen-activated protein kinases in articular chondrocytes. Arthritis Res Ther 2005; 7(5): R915-26. [http://dx.doi.org/10.1186/ar1763] [PMID: 16207333]

[11] Morgan MP, Whelan LC, Sallis JD, McCarthy CJ, Fitzgerald DJ, McCarthy GM. Basic calcium phosphate crystal-induced prostaglandin E2 production in human fibroblasts: role of cyclooxygenase 1, cyclooxygenase 2, and interleukin-1beta. Arthritis Rheum 2004; 50(5): 1642-9. [http://dx.doi.org/10.1002/art.20223] [PMID: 15146435]

[12] McCarty DJ. Crystal-induced inflammation of the joints. Annu Rev Med 1970; 21: 357-66. [http://dx.doi.org/10.1146/annurev.me.21.020170.002041] [PMID: 4913950]

[13] Ea HK, Chobaz V, Nguyen C, et al. Pathogenic role of basic calcium phosphate crystals in destructive arthropathies. PLoS One 2013; 8(2): e57352. [http://dx.doi.org/10.1371/journal.pone.0057352] [PMID: 23468973]

[14] Nair D, Misra RP, Sallis JD, Cheung HS. Phosphocitrate inhibits a basic calcium phosphate and calcium pyrophosphate dihydrate crystalinduced mitogen-activated protein kinase cascade signal transduction pathway. J Biol Chem 1997; 272(30): 18920-5. [http://dx.doi.org/10.1074/jbc.272.30.18920] [PMID: 9228071]

[15] Cheung HS, Sallis JD, Struve JA. Specific inhibition of basic calcium phosphate and calcium pyrophosphate crystal-induction of metalloproteinase synthesis by phosphocitrate. Biochim Biophys Acta 1996; 1315(2): 105-11. [http://dx.doi.org/10.1016/0925-4439(95)00106-9] [PMID: 8608166]

[16] Sun Y, Reuben P, Wenger L, Sallis JD, Demadis KD, Cheung HS. Inhibition of calcium phosphate-DNA coprecipitates induced cell death by phosphocitrates. Front Biosci 2005; 10: 803-8. [http://dx.doi.org/10.2741/1574] [PMID: 15569620]

[17] Cheung HS. Phosphocitrate as a potential therapeutic strategy for crystal deposition disease. Curr Rheumatol Rep 2001; 3(1): 24-8. [http://dx.doi.org/10.1007/s11926-001-0047-9] [PMID: 11794133]

[18] Cheung HS, Sallis JD, Demadis KD, Wierzbicki A. Phosphocitrate blocks calcification-induced articular joint degeneration in a guinea pig model. Arthritis Rheum 2006; 54(8): 2452-61. [http://dx.doi.org/10.1002/art.22017] [PMID: 16869019]

[19] Sun Y, Mauerhan DR, Franklin AM, Norton J, Hanley EN Jr, Gruber HE. Phosphocitrate is potentially a disease-modifying drug for noncrystal-associated osteoarthritis. Biomed Res Int 2013. [http://dx.doi.org/10.1155/2013/326267]

[20] Sun Y, Roberts A, Mauerhan DR, Sun AR, Norton HJ, Hanley EN Jr. Biological activities of phosphocitrate: a potential meniscal protective agent. Biomed Res Int 2013. [http://dx.doi.org/10.1155/2013/726581]

[21] Sun Y, Mauerhan DR, Steuerwald NM, Ingram J, Kneis1 JS, Hanley EN Jr. Expression of phosphocitrate-targeted genes in osteoarthritis menisci. Biomed Res Int 2014 [http://dx.doi.org/10.1155/2014/210469]

[22] Sun Y, Haines N, Roberts A, et al. Disease-modifying effects of phosphocitrate and phosphocitrate- $\beta$-ethyl ester on partial meniscectomyinduced osteoarthritis. BMC Musculoskelet Disord 2015; 16: 270. [http://dx.doi.org/10.1186/s12891-015-0724-x] [PMID: 26424660]

[23] Turhanen PA, Demadis KD, Peräniemi S, Vepsäläinen JJ. A novel strategy for the preparation of naturally occurring phosphocitrate and its partially esterified derivatives. J Org Chem 2007; 72(4): 1468-71. [http://dx.doi.org/10.1021/jo061709c] [PMID: 17288391]

[24] Sun Y, Mauerhan D, Hanley EN, Gruber H. Analysis of Meniscal Degeneration and Meniscal Gene Expression BMC Musculoskelatal Disorder 2010; 11(19)

[25] Reuben PM, Wenger L, Cruz M, Cheung HS. Induction of matrix metalloproteinase- 8 in human fibroblasts by basic calcium phosphate and calcium pyrophosphate dihydrate crystals: effect of phosphocitrate. Connect Tissue Res 2001; 42(1): 1-12. [http://dx.doi.org/10.3109/03008200109014244] [PMID: 11696984] 
[26] Cheung HS, Sallis JD, Mitchell PG, Struve JA. Inhibition of basic calcium phosphate crystal-induced mitogenesis by phosphocitrate. Biochem Biophys Res Commun 1990; 171(1): 20-5. [http://dx.doi.org/10.1016/0006-291X(90)91350-2] [PMID: 2118343]

[27] Sun Y, Mauerhan DR, Franklin AM, Zinchenko N, Norton HJ, Hanley EN Jr, et al. Fibroblast-like synoviocytes induce calcium mineral formation and deposition. Arthritis 2014. [http://dx.doi.org/10.1155/2014/812678]

[28] Mankin HJ, Lippiello L. Biochemical and metabolic abnormalities in articular cartilage from osteo-arthritic human hips. J Bone Joint Surg Am 1970; 52(3): 424-34.

[http://dx.doi.org/10.2106/00004623-197052030-00002] [PMID: 4246573]

[29] Lotz MK, Otsuki S, Grogan SP, Sah R, Terkeltaub R, DLima D. Cartilage cell clusters. Arthritis Rheum 2010; 62(8): $2206-18$. [http://dx.doi.org/10.1002/art.27528] [PMID: 20506158]

[30] Pfander D, Körtje D, Weseloh G, Swoboda B. [Cell proliferation in human arthrotic joint cartilage]. Z Orthop Ihre Grenzgeb 2001; 139(5): 375-81. [Cell proliferation in human arthrotic joint cartilage]. [http://dx.doi.org/10.1055/s-2001-17977] [PMID: 11605286]

[31] Hashimoto S, Ochs RL, Komiya S, Lotz M. Linkage of chondrocyte apoptosis and cartilage degradation in human osteoarthritis. Arthritis Rheum 1998; 41(9): 1632-8 [http://dx.doi.org/10.1002/1529-0131(199809)41:9<1632::AID-ART14>3.0.CO;2-A] [PMID: 9751096]

[32] Blanco FJ, Guitian R, Vázquez-Martul E, de Toro FJ, Galdo F. Osteoarthritis chondrocytes die by apoptosis. A possible pathway for osteoarthritis pathology. Arthritis Rheum 1998; 41(2): 284-9.

[http://dx.doi.org/10.1002/1529-0131(199802)41:2<284::AID-ART12>3.0.CO;2-T] [PMID: 9485086]

[33] von der Mark K, Kirsch T, Nerlich A, et al. Type X collagen synthesis in human osteoarthritic cartilage. Indication of chondrocyte hypertrophy. Arthritis Rheum 1992; 35(7): 806-11. [http://dx.doi.org/10.1002/art.1780350715] [PMID: 1622419]

[34] Pullig O, Weseloh G, Ronneberger D, Käkönen S, Swoboda B. Chondrocyte differentiation in human osteoarthritis: expression of osteocalcin in normal and osteoarthritic cartilage and bone. Calcif Tissue Int 2000; 67(3): 230-40. [http://dx.doi.org/10.1007/s002230001108] [PMID: 10954778]

[35] Johnson K, Hashimoto S, Lotz M, Pritzker K, Goding J, Terkeltaub R. Up-regulated expression of the phosphodiesterase nucleotide pyrophosphatase family member PC-1 is a marker and pathogenic factor for knee meniscal cartilage matrix calcification. Arthritis Rheum 2001; 44(5): 1071-81. [http://dx.doi.org/10.1002/1529-0131(200105)44:5<1071::AID-ANR187>3.0.CO;2-3] [PMID: 11352238]

[36] Cheung HS, Kurup IV, Sallis JD, Ryan LM. Inhibition of calcium pyrophosphate dihydrate crystal formation in articular cartilage vesicles and cartilage by phosphocitrate. J Biol Chem 1996; 271(45): 28082-5. [http://dx.doi.org/10.1074/jbc.271.45.28082] [PMID: 8910421]

[37] Cheung HS, Ryan LM. Phosphocitrate blocks nitric oxide-induced calcification of cartilage and chondrocyte-derived apoptotic bodies. Osteoarthritis Cartilage 1999; 7(4): 409-12. [http://dx.doi.org/10.1053/joca.1998.0227] [PMID: 10419783]

[38] Van Roon JA, Lafeber FP. Role of interleukin-7 in degenerative and inflammatory joint diseases. Arthritis Res Ther 2008 ; $10(2)$ : 107. [http://dx.doi.org/10.1186/ar2395] [PMID: 18466642]

[39] Von Eyss B, Maaskola J, Memczak S, et al. The SNF2-like helicase HELLS mediates E2F3-dependent transcription and cellular transformation. EMBO J 2012; 31(4): 972-85. [http://dx.doi.org/10.1038/emboj.2011.451] [PMID: 22157815]

[40] Zhao H, Qiu GX, Guan J, Zhao Y, Zhou X. [Correlation of apoptosis of articular chondrocytes in osteoarthritis with degree of cartilage destruction and expression of apoptosis-related proteins: surviving, caspase-3, and Bcl-xl]. Zhonghua Yi Xue Za Zhi 2008; 88(19): 1339-41. [PMID: 18956705]

[41] Van der Kraan PM. Age-related alterations in TGF beta signaling as a causal factor of cartilage degeneration in osteoarthritis. Biomed Mater Eng 2014; 24(1)(Suppl.): 75-80. [PMID: 24928920]

[42] Cao Y, Wang C, Zhang X, et al. Selective small molecule compounds increase BMP-2 responsiveness by inhibiting Smurf1-mediated Smad1/5 degradation. Sci Rep 2014; 4: 4965. [http://dx.doi.org/10.1038/srep04965] [PMID: 24828823]

[43] Hsu CW, Liu S, Hsu E, Hollinger JO. Inhibition of rhBMP-2-induced ALP activity by intracellular delivery of SMURF1 in murine calvarial preosteoblast cells. J Biomed Mater Res A 2014; 102(11): 4037-43. [http://dx.doi.org/10.1002/jbm.a.35046] [PMID: 24288199]

[44] Murakami K, Mathew R, Huang J, et al. Smurf1 ubiquitin ligase causes downregulation of BMP receptors and is induced in monocrotaline and hypoxia models of pulmonary arterial hypertension. Exp Biol Med (Maywood) 2010; 235(7): 805-13. [http://dx.doi.org/10.1258/ebm.2010.009383] [PMID: 20558834]

[45] Okabe T, Ohmori Y, Tanigami A, et al. Detection of gene expression in synovium of patients with osteoarthritis using a random sequencing 
method. Acta Orthop 2007; 78(5): 687-92.

[http://dx.doi.org/10.1080/17453670710014400] [PMID: 17966030]

[46] Busby WH Jr, Yocum SA, Rowland M, et al. Complement 1s is the serine protease that cleaves IGFBP-5 in human osteoarthritic joint fluid. Osteoarthritis Cartilage 2009; 17(4): 547-55. [http://dx.doi.org/10.1016/j.joca.2008.08.004] [PMID: 18930415]

[47] Clemmons DR, Busby WH Jr, Garmong A, et al. Inhibition of insulin-like growth factor binding protein 5 proteolysis in articular cartilage and joint fluid results in enhanced concentrations of insulin-like growth factor 1 and is associated with improved osteoarthritis. Arthritis Rheum 2002; 46(3): 694-703. [http://dx.doi.org/10.1002/art.10222] [PMID: 11920405]

[48] Liu H, Pan H, Yang H, et al. LIM mineralization protein-1 suppresses TNF- $\alpha$ induced intervertebral disc degeneration by maintaining nucleus pulposus extracellular matrix production and inhibiting matrix metalloproteinases expression. J Orthop Res 2015; 33(3): $294-303$. [http://dx.doi.org/10.1002/jor.22732] [PMID: 25336289]

[49] Jeffries MA, Donica M, Baker LW, et al. Genome-wide DNA methylation study identifies significant epigenomic changes in osteoarthritic cartilage. Arthritis Rheumatol 2014; 66(10): 2804-15. [http://dx.doi.org/10.1002/art.38762] [PMID: 24980887]

[50] Liu Y, Hou R, Yin R, Yin W. Correlation of bone morphogenetic protein-2 levels in serum and synovial fluid with disease severity of knee osteoarthritis. Med Sci Monit 2015; 21: 363-70. [http://dx.doi.org/10.12659/MSM.892160] [PMID: 25644704]

[51] Papathanasiou I, Malizos KN, Tsezou A. Bone morphogenetic protein-2-induced Wnt/ $\beta$-catenin signaling pathway activation through enhanced low-density-lipoprotein receptor-related protein 5 catabolic activity contributes to hypertrophy in osteoarthritic chondrocytes. Arthritis Res Ther 2012; 14(2): R82. [http://dx.doi.org/10.1186/ar3805] [PMID: 22513174]

[52] Blaney Davidson EN, Vitters EL, Bennink MB, et al. Inducible chondrocyte-specific overexpression of BMP2 in young mice results in severe aggravation of osteophyte formation in experimental OA without altering cartilage damage. Ann Rheum Dis 2015; 74(6): 1257-64. [http://dx.doi.org/10.1136/annrheumdis-2013-204528] [PMID: 24448347]

[53] Andrés Cerezo L, Kuklová M, Hulejová H, et al. The level of fatty acid-binding protein 4, a novel adipokine, is increased in rheumatoid arthritis and correlates with serum cholesterol levels. Cytokine 2013; 64(1): 441-7. [http://dx.doi.org/10.1016/j.cyto.2013.05.001] [PMID: 23714112]

[54] Kralisch S, Fasshauer M. Adipocyte fatty acid binding protein: a novel adipokine involved in the pathogenesis of metabolic and vascular disease? Diabetologia 2013; 56(1): 10-21 [http://dx.doi.org/10.1007/s00125-012-2737-4] [PMID: 23052058]

[55] Qu B, Liu O, Fang X, et al. Distal-less homeobox 2 promotes the osteogenic differentiation potential of stem cells from apical papilla. Cell Tissue Res 2014; 357(1): 133-43. [http://dx.doi.org/10.1007/s00441-014-1833-9] [PMID: 24756434]

[56] Chijimatsu R, Kunugiza Y, Taniyama Y, Nakamura N, Tomita T, Yoshikawa H. Expression and pathological effects of periostin in human osteoarthritis cartilage. BMC Musculoskelet Disord 2015; 16: 215. [http://dx.doi.org/10.1186/s12891-015-0682-3] [PMID: 26289167]

[57] Viale-Bouroncle S, Klingelhöffer C, Ettl T, Morsczeck C. The WNT inhibitor APCDD1 sustains the expression of $\beta$-catenin during the osteogenic differentiation of human dental follicle cells. Biochem Biophys Res Commun 2015; 457(3): 314-7. [http://dx.doi.org/10.1016/j.bbrc.2014.12.107] [PMID: 25592970]

[58] Chang TH, Hsieh FL, Zebisch M, Harlos K, Elegheert J, Jones EY. Structure and functional properties of Norrin mimic Wnt for signalling with Frizzled4, Lrp5/6, and proteoglycan. eLife 2015; 9: 4. [http://dx.doi.org/10.7554/eLife.06554] [PMID: 26158506]

[59] Corr M. Wnt-beta-catenin signaling in the pathogenesis of osteoarthritis. Nat Clin Pract Rheumatol 2008; 4(10): 550-6. [http://dx.doi.org/10.1038/ncprheum0904] [PMID: 18820702]

[60] Bhattaram P, Penzo-Méndez A, Kato K, et al. SOXC proteins amplify canonical WNT signaling to secure nonchondrocytic fates in skeletogenesis. J Cell Biol 2014; 207(5): 657-71.

[http://dx.doi.org/10.1083/jcb.201405098] [PMID: 25452386]

[61] Miao CG, Shi WJ, Xiong YY, et al. miR-375 regulates the canonical Wnt pathway through FZD8 silencing in arthritis synovial fibroblasts. Immunol Lett 2015; 164(1): 1-10. [http://dx.doi.org/10.1016/j.imlet.2015.01.003] [PMID: 25619565]

\section{(C) 2017 Sun et al.}

This is an open access article distributed under the terms of the Creative Commons Attribution 4.0 International Public License (CC-BY 4.0), a copy of which is available at: (https:/creativecommons.org/licenses/by/4.0/legalcode). This license permits unrestricted use, distribution, and reproduction in any medium, provided the original author and source are credited. 